\title{
An Expedient Synthesis, Acetylcholinesterase Inhibitory Activity, and Molecular Modeling Study of Highly Functionalized Hexahydro-1,6-naphthyridines
}

\author{
Abdulrahman I. Almansour, ${ }^{1}$ Raju Suresh Kumar, ${ }^{1}$ Natarajan Arumugam, \\ Alireza Basiri, ${ }^{2}$ Yalda Kia, ${ }^{3}$ and Mohamed Ashraf $\mathrm{Ali}^{4}$ \\ ${ }^{1}$ Department of Chemistry, College of Science, King Saud University, P.O. Box 2455, Riyadh 11451, Saudi Arabia \\ ${ }^{2}$ School of Pharmaceutical Sciences, Universiti Sains Malaysia, 11800 Minden, Penang, Malaysia \\ ${ }^{3}$ School of Chemical Sciences, Universiti Sains Malaysia, 11800 Minden, Penang, Malaysia \\ ${ }^{4}$ Pharmacogenetic and Novel Therapeutic Institute for Research in Molecular Medicine, Universiti Sains Malaysia, \\ 11800 Penang, Malaysia
}

Correspondence should be addressed to Raju Suresh Kumar; rajusures@gmail.com

Received 17 November 2014; Revised 9 January 2015; Accepted 9 January 2015

Academic Editor: Miroslav Pohanka

Copyright (C) 2015 Abdulrahman I. Almansour et al. This is an open access article distributed under the Creative Commons Attribution License, which permits unrestricted use, distribution, and reproduction in any medium, provided the original work is properly cited.

A series of hexahydro-1,6-naphthyridines were synthesized in good yields by the reaction of 3,5-bis[(E)-arylmethylidene] tetrahydro-4(1H)-pyridinones with cyanoacetamide in the presence of sodium ethoxide under simple mixing at ambient temperature for 6-10 minutes and were assayed for their acetylcholinesterase (AChE) inhibitory activity using colorimetric Ellman's method. Compound $4 \mathbf{e}$ with methoxy substituent at ortho-position of the phenyl rings displayed the maximum inhibitory activity with $\mathrm{IC}_{50}$ value of $2.12 \mu \mathrm{M}$. Molecular modeling simulation of $4 \mathbf{e}$ was performed using three-dimensional structure of Torpedo californica AChE (TcAChE) enzyme to disclose binding interaction and orientation of this molecule into the active site gorge of the receptor.

\section{Introduction}

Alzheimer's disease $(\mathrm{AD})$ is associated with loss of cholinergic neurons in basal forebrain, which results in loss or failure of memory which slowly worsens and eventually incapacitates the patients [1,2]. According to the World Alzheimer report, $\mathrm{AD}$ is one among the most significant social, health, and economic crises of the 21st century [3]. Although the exact factors initiating $\mathrm{AD}$ are unclear, genetic and environmental factors have been implicated [4]. In general, pharmacological therapies have twin objectives: (i) to prevent the loss of the neurons and (ii) to restore the cholinergic functions of $A D$ patients. Cholinesterase inhibitors have been used clinically for symptomatic treatment of $\mathrm{AD}$ [5]. Acetylcholinesterase (AChE) enzyme is involved in the breakdown of acetylcholine in the brain and inhibition of this enzyme may increase the efficacy of treatment and broaden the indications [6]. Effects of cholinesterase inhibitors are mainly due to enhancement of cholinergic transmission at cholinergic autonomic synapses and at the neuromuscular junction [7].

AChE inhibitors are one of the most actively investigated classes of compounds in the search for an effective treatment of $\mathrm{AD}$. Although there are many ongoing research activities in the search of drugs for treating $\mathrm{AD}$, only few drugs like galantamine, donepezil, and rivastigmine are now available [8], and these drugs do not show potential cure rates; additional treatments are still being developed. The treatment of AD still remains an area of significant unmet need, with drugs that only target the symptoms of the disease. Therefore, there is considerable need for disease-modifying therapies. To meet the need of disease-modifying drugs for $\mathrm{AD}$, in recent years, new approaches have emerged in 
medicinal chemistry. In particular the concept has recently been proposed that due to the multifactorial and complex etiology of $\mathrm{AD}$, the modulation of a single factor might not be sufficient to produce the desired efficacy. Researchers are now paying attention to the design of structures that could be able to simultaneously interact with different targets involved in the pathogenic process $[9,10]$.

Naphthyridine structural motif has been extensively synthesized and incorporated into biologically active molecules [11]. In particular, 1,6-naphthyridines exhibit a broad spectrum of biological activities such as being inhibitor of HIV1 integrase [12, 13], HCMV [14, 15], FGF receptor-1 tyrosine kinase [16], and the enzyme acetylcholinesterase [17]. Many routes for the syntheses of 1,6-naphthyridines derivatives have previously been reported [18-21]. In continuation of our previous work towards the synthesis of novel hybrid heterocycles employing new synthetic methodologies and/or their potential as inhibitors of AChE [22-26], herein we report the synthesis and AChE inhibitory activities of nitrogen heterocyclic hybrids comprising naphthyridine structural motif.

\section{Materials and Methods}

\subsection{Chemistry}

General Methods. Melting points were measured in KRUSS melting point meter using open capillary tubes and are uncorrected. ${ }^{1} \mathrm{H}$ and ${ }^{13} \mathrm{C}$ NMR spectra were recorded on a Bruker $300 \mathrm{MHz}$ instrument in DMSO using TMS as internal standard. Standard Bruker software was used throughout. Chemical shifts are given in parts per million $(\delta$-scale) and the coupling constants are given in Hertz. IR spectra were recorded in a Perkin Elmer system 2000 FT IR instrument $(\mathrm{KBr})$. Elemental analyses were performed on a Perkin Elmer 2400 Series II Elemental CHNS analyser. Mass spectra were recorded in Agilent technologies 7820A GC-MS system.

\subsubsection{General Procedure for the Synthesis of Naphthyridines}

$(\mathbf{4 a}-\boldsymbol{k})$. A mixture of 3,5-bis[(E)-arylmethylidene]tetrahydro-4(1H)-pyridinones (1 mmol) and 2-cyanoacetamide $(1 \mathrm{mmol})$ in ethanol $(200 \mu \mathrm{L})$ in the presence of catalytic amount of sodium ethoxide ( $5 \mathrm{mg}$ ) were ground well in a semimicro boiling tube at ambient temperature for about 6-10 min. After completion of the reaction as evident from TLC, water $(50 \mathrm{~mL})$ was added to the reaction mixture and the product was filtered, washed with water, and dried in vacuo.

(E)-8-Benzylidene-2-oxo-4-phenyl-1,2,5,6,7,8-hexahydro-1,6naphthyridine-3-carbonitrile (4a). Pale yellow solid; IR ( $\mathrm{KBr}$ ) $v_{\max } 3372,2945,2213,1642,1625 \mathrm{~cm}^{-1} ;{ }^{1} \mathrm{H}$ NMR $(300 \mathrm{MHz}$, DMSO): $\delta_{\mathrm{H}} 3.15\left(\mathrm{~d}, J=15.9 \mathrm{~Hz}, 1 \mathrm{H}, 5-\mathrm{CH}_{2}\right), 3.35(\mathrm{~d}, J=$ $\left.15.9 \mathrm{~Hz}, 1 \mathrm{H}, 5-\mathrm{CH}_{2}\right), 3.60\left(\mathrm{~d}, J=15.6 \mathrm{~Hz}, 1 \mathrm{H}, 7-\mathrm{CH}_{2}\right), 3.69$ (d, $\left.J=15.6 \mathrm{~Hz}, 1 \mathrm{H}, 7-\mathrm{CH}_{2}\right), 7.07-7.38(\mathrm{~m}, 10 \mathrm{H}, \mathrm{Ar}-\mathrm{H}), 7.81(\mathrm{~s}, 1 \mathrm{H}$, Arylmethylidene-H), 8.15 (s, $1 \mathrm{H}, \mathrm{NH}) .{ }^{13} \mathrm{C}$ NMR $(75 \mathrm{MHz}$, DMSO): $\delta_{\mathrm{C}} 45.48,45.76,79.31,101.70,115.22,116.94,126.21$, $127.81,128.84,129.50,130.78,131.10,134.71,135.54,137.90$,
146.85, 159.18, 162.83. EIMS: $m / z 341[\mathrm{M}+1]$. Anal. calcd for $\mathrm{C}_{22} \mathrm{H}_{17} \mathrm{~N}_{3} \mathrm{O}$ : C, 77.86; $\mathrm{H}, 5.05$; N, 12.38; found: C, 77.69; $\mathrm{H}$, $5.22 ; \mathrm{N}, 12.25 \%$.

(E)-8-(2-Methylbenzylidene)-2-oxo-4-(o-tolyl)-1,2,5,6,7,8-hexahydro-1,6-naphthyridine-3-carbonitrile (4b). Yellow solid; IR $(\mathrm{KBr}) v_{\max } 3380,2948,2210,1640,1627 \mathrm{~cm}^{-1} ;{ }^{1} \mathrm{H} \mathrm{NMR}$ (300 MHz, DMSO): $\delta_{\mathrm{H}} 2.13\left(\mathrm{~s}, 3 \mathrm{H}, \mathrm{CH}_{3}\right), 2.30\left(\mathrm{~s}, 3 \mathrm{H}, \mathrm{CH}_{3}\right.$ ), $3.14\left(\mathrm{~d}, J=15.9 \mathrm{~Hz}, 1 \mathrm{H}, 5-\mathrm{CH}_{2}\right), 3.33(\mathrm{~d}, J=15.9 \mathrm{~Hz}, 1 \mathrm{H}$, $\left.5-\mathrm{CH}_{2}\right), 3.62\left(\mathrm{~d}, J=15.6 \mathrm{~Hz}, 1 \mathrm{H}, 7-\mathrm{CH}_{2}\right), 3.68(\mathrm{~d}, J=$ $15.6 \mathrm{~Hz}, 1 \mathrm{H}, 7-\mathrm{CH}_{2}$ ), 7.04-7.35 (m, 8H, Ar-H), 7.80 (s, 1H, Arylmethylidene-H), 8.14 (s, $1 \mathrm{H}, \mathrm{NH}) .{ }^{13} \mathrm{C} \mathrm{NMR}(75 \mathrm{MHz}$, DMSO): $\delta_{\mathrm{C}} 19.75,20.56,45.43,45.82,79.76,101.32,115.23$, $116.91,126.21,127.03,127.79,128.89,129.33,129.53,129.92$, $130.78,131.19,134.76,135.42,135.55,137.91,146.96,159.08$, 162.92. EIMS: $m / z 369[\mathrm{M}+1]$. Anal. calcd for $\mathrm{C}_{24} \mathrm{H}_{21} \mathrm{~N}_{3} \mathrm{O}: \mathrm{C}$, 78.45; H, 5.76; N, 11.44; found: C, 78.32; H, 5.98; N, 11.29\%.

(E)-8-(2-Chlorobenzylidene)-4-(2-chlorophenyl)-2-oxo-1,2,5,6, 7,8-hexahydro-1,6-naphthyridine-3-carbonitrile (4c). Pale yellow solid; IR (KBr) $\nu_{\max } 3384,2950,2214,1642,1625 \mathrm{~cm}^{-1}$; ${ }^{1} \mathrm{H}$ NMR (300 MHz, DMSO): $\delta_{\mathrm{H}} 3.16$ (d, $J=15.6 \mathrm{~Hz}, 1 \mathrm{H}, 5-$ $\left.\mathrm{CH}_{2}\right), 3.34\left(\mathrm{~d}, J=15.6 \mathrm{~Hz}, 1 \mathrm{H}, 5-\mathrm{CH}_{2}\right), 3.61(\mathrm{~d}, J=15.6 \mathrm{~Hz}$, $\left.1 \mathrm{H}, 7-\mathrm{CH}_{2}\right), 3.68\left(\mathrm{~d}, J=15.6 \mathrm{~Hz}, 1 \mathrm{H}, 7-\mathrm{CH}_{2}\right), 7.10-7.36(\mathrm{~m}, 8 \mathrm{H}$, Ar-H), 7.81 (s, 1H, Arylmethylidene-H), 8.12 (s, 1H, NH). ${ }^{13} \mathrm{C}$ NMR $(75 \mathrm{MHz}, \mathrm{DMSO}): \delta_{\mathrm{C}} 45.38,45.95,79.70,101.64,115.21$, $116.90,126.28,127.01,127.85,128.90,129.31,129.54,129.93$, $130.69,131.26,134.73,135.40,135.52,137.90,146.91,159.13$, 162.90. EIMS: $m / z 408[\mathrm{M}+1]$. Anal. calcd for $\mathrm{C}_{22} \mathrm{H}_{15} \mathrm{Cl}_{2} \mathrm{~N}_{3} \mathrm{O}$ : C, 64.72; H, 3.70; N, 10.29; found: C, 64.80; H, 3.87; N, 10.48\%.

(E)-8-(2-Bromobenzylidene)-4-(2-bromophenyl)-2-oxo-1,2,5,6, 7,8-hexahydro-1,6-naphthyridine-3-carbonitrile (4d). Pale yellow solid; IR (KBr) $v_{\max } 3381,2950,2210,1644,1626 \mathrm{~cm}^{-1}$; ${ }^{1} \mathrm{H}$ NMR (300 MHz, DMSO): $\delta_{\mathrm{H}} 3.18$ (d, $J=15.9 \mathrm{~Hz}, 1 \mathrm{H}, 5-$ $\left.\mathrm{CH}_{2}\right), 3.34\left(\mathrm{~d}, J=15.9 \mathrm{~Hz}, 1 \mathrm{H}, 5-\mathrm{CH}_{2}\right), 3.62(\mathrm{~d}, J=15.9 \mathrm{~Hz}$, $\left.1 \mathrm{H}, 7-\mathrm{CH}_{2}\right), 3.69\left(\mathrm{~d}, \mathrm{~J}=15.6 \mathrm{~Hz}, 1 \mathrm{H}, 7-\mathrm{CH}_{2}\right), 7.16-7.39(\mathrm{~m}, 8 \mathrm{H}$, Ar-H), 7.82 (s, 1H, Arylmethylidene-H), 8.09 (s, $1 \mathrm{H}, \mathrm{NH}) .{ }^{13} \mathrm{C}$ NMR (75 MHz, DMSO): $\delta_{\mathrm{C}} 44.93,45.80,79.78,101.61,115.20$, $116.96,126.25,127.05,127.81,128.98,129.35,129.62,129.92$, $130.73,131.24,134.71,135.43,135.51,137.93,146.90,159.17$, 162.92. EIMS: $m / z 498[\mathrm{M}+1]$. Anal. calcd for $\mathrm{C}_{22} \mathrm{H}_{15} \mathrm{Br}_{2} \mathrm{~N}_{3} \mathrm{O}$ : C, 53.15; H, 3.04; N, 8.45; found: C, 53.38; H, 3.16; N, 8.37\%.

(E)-8-(2-Methoxybenzylidene)-4-(2-methoxyphenyl)-2-oxo-1,2, 5,6,7,8-hexahydro-1,6-naphthyridine-3-carbonitrile (4e). Yellow solid; IR (KBr) $\nu_{\max } 3385,2944,2210,1641,1627 \mathrm{~cm}^{-1} ;{ }^{1} \mathrm{H}$ NMR (300 MHz, DMSO): $\delta_{\mathrm{H}} 3.14\left(\mathrm{~d}, J=15.6 \mathrm{~Hz}, 1 \mathrm{H}, 5-\mathrm{CH}_{2}\right)$, $3.31\left(\mathrm{~d}, J=15.6 \mathrm{~Hz}, 1 \mathrm{H}, 5-\mathrm{CH}_{2}\right), 3.60(\mathrm{~d}, J=15.6 \mathrm{~Hz}, 1 \mathrm{H}, 7-$ $\mathrm{CH}_{2}$ ), 3.68 (d, $\left.J=15.6 \mathrm{~Hz}, 1 \mathrm{H}, 7-\mathrm{CH}_{2}\right), 3.74$ (s, $3 \mathrm{H}, \mathrm{OCH}_{3}$ ), $3.82\left(\mathrm{~s}, 3 \mathrm{H}, \mathrm{OCH}_{3}\right), 7.11-7.38(\mathrm{~m}, 8 \mathrm{H}, \mathrm{Ar}-\mathrm{H}), 7.83(\mathrm{~s}, 1 \mathrm{H}$, Arylmethylidene-H), 8.10 (s, $1 \mathrm{H}, \mathrm{NH}) .{ }^{13} \mathrm{C}$ NMR $(75 \mathrm{MHz}$, DMSO): $\delta_{\mathrm{C}} 45.39,45.93,55.51,55.70,79.70,101.67,114.20$, $114.81,115.20,116.94,126.31,127.81,128.93,129.56,130.66$, $131.29,134.70,135.42,137.90,146.95,159.07,159.14,160.04$, 162.95. EIMS: $m / z 401[\mathrm{M}+1]$. Anal. calcd for $\mathrm{C}_{24} \mathrm{H}_{21} \mathrm{~N}_{3} \mathrm{O}_{3}$ : C, 72.16; H, 5.30; N, 10.52; found: C, 72.30; H, 5.53; N, 10.39\%. 
(E)-8-(2,4-Dichlorobenzylidene)-4-(2,4-dichlorophenyl)-2-oxo1,2,5,6,7,8-hexahydro-1,6-naphthyridine-3-carbonitrile (4f). Pale yellow solid; IR (KBr) $v_{\max } 3380,2951,2219,1646$, $1628 \mathrm{~cm}^{-1}$; ${ }^{1} \mathrm{H}$ NMR $(300 \mathrm{MHz}, \mathrm{DMSO}): \delta_{\mathrm{H}} 3.18(\mathrm{~d}, J=$ $\left.15.9 \mathrm{~Hz}, 1 \mathrm{H}, 5-\mathrm{CH}_{2}\right), 3.37\left(\mathrm{~d}, J=15.9 \mathrm{~Hz}, 1 \mathrm{H}, 5-\mathrm{CH}_{2}\right), 3.60$ $\left(\mathrm{d}, J=15.6 \mathrm{~Hz}, 1 \mathrm{H}, 7-\mathrm{CH}_{2}\right), 3.68\left(\mathrm{~d}, J=15.6 \mathrm{~Hz}, 1 \mathrm{H}, 7-\mathrm{CH}_{2}\right)$, 7.14-7.42 (m, 6H, Ar-H), 7.82 (s, 1H, Arylmethylidene-H), 8.09 (s, $1 \mathrm{H}, \mathrm{NH}) .{ }^{13} \mathrm{C} \mathrm{NMR}(75 \mathrm{MHz}, \mathrm{DMSO}): \delta_{\mathrm{C}} 45.35$, $45.97,79.65,101.62,115.26,116.81,126.30,127.12,127.87,128.94$, $129.43,129.60,129.94,130.74,131.27,134.72,135.47,135.53$, 137.94, 146.97, 159.16, 162.95. EIMS: $m / z 478[\mathrm{M}+1]$. Anal. calcd for $\mathrm{C}_{22} \mathrm{H}_{13} \mathrm{Cl}_{4} \mathrm{~N}_{3} \mathrm{O}$ : C, 55.38; $\mathrm{H}, 2.75 ; \mathrm{N}, 8.81$; found: $\mathrm{C}$, $55.29 ; \mathrm{H}, 2.92 ; \mathrm{N}, 8.70 \%$.

(E)-8-(3-Nitrobenzylidene)-4-(3-nitrophenyl)-2-oxo-1,2,5,6,7, 8-hexahydro-1,6-naphthyridine-3-carbonitrile (4g). Yellow solid; IR (KBr) $v_{\max } 3389,2942,2210,1645,1626 \mathrm{~cm}^{-1} ;{ }^{1} \mathrm{H}$ $\operatorname{NMR}(300 \mathrm{MHz}, \mathrm{DMSO}): \delta_{\mathrm{H}} 3.21\left(\mathrm{~d}, J=15.9 \mathrm{~Hz}, 1 \mathrm{H}, 5-\mathrm{CH}_{2}\right)$, $3.39\left(\mathrm{~d}, J=15.9 \mathrm{~Hz}, 1 \mathrm{H}, 5-\mathrm{CH}_{2}\right), 3.61(\mathrm{~d}, J=15.6 \mathrm{~Hz}, 1 \mathrm{H}, 7-$ $\left.\mathrm{CH}_{2}\right), 3.70\left(\mathrm{~d}, \mathrm{~J}=15.6 \mathrm{~Hz}, 1 \mathrm{H}, 7-\mathrm{CH}_{2}\right), 7.12-7.38(\mathrm{~m}, 8 \mathrm{H}, \mathrm{Ar}-$ $\mathrm{H}), 7.80$ (s, $1 \mathrm{H}$, Arylmethylidene-H), 8.11 (s, $1 \mathrm{H}, \mathrm{NH}) .{ }^{13} \mathrm{C}$ NMR (75 MHz, DMSO): $\delta_{\mathrm{C}} 45.32,45.95,79.66,101.60,115.24$, $116.79,126.31,127.15,127.86,128.93,129.41,129.64,129.96$, $130.75,131.30,134.71,135.49,135.61,137.92,146.95,159.14$, 162.93. EIMS: $m / z 431[\mathrm{M}+1]$. Anal. calcd for $\mathrm{C}_{22} \mathrm{H}_{15} \mathrm{~N}_{5} \mathrm{O}_{5}$ : C, 61.54; H, 3.52; N, 16.31; found: C, 61.27; H, 3.75; N, 16.18\%.

(E)-8-(4-Methylbenzylidene)-2-oxo-4-(p-tolyl)-1,2,5,6,7,8hexahydro-1,6-naphthyridine-3-carbonitrile (4h). Pale yellow solid; IR (KBr) $\nu_{\max } 3387,2940,2212,1647,1625 \mathrm{~cm}^{-1} ;{ }^{1} \mathrm{H}$ NMR (300 MHz, DMSO): $\delta_{\mathrm{H}} 2.25\left(\mathrm{~s}, 3 \mathrm{H}, \mathrm{CH}_{3}\right), 2.29(\mathrm{~s}, 3 \mathrm{H}$, $\left.\mathrm{CH}_{3}\right), 3.20\left(\mathrm{~d}, J=15.9 \mathrm{~Hz}, 1 \mathrm{H}, 5-\mathrm{CH}_{2}\right), 3.41(\mathrm{~d}, J=15.9 \mathrm{~Hz}$, $\left.1 \mathrm{H}, 5-\mathrm{CH}_{2}\right), 3.63\left(\mathrm{~d}, J=15.6 \mathrm{~Hz}, 1 \mathrm{H}, 7-\mathrm{CH}_{2}\right), 3.72(\mathrm{~d}, J=$ $\left.15.6 \mathrm{~Hz}, 1 \mathrm{H}, 7-\mathrm{CH}_{2}\right), 7.12-7.40(\mathrm{~m}, 8 \mathrm{H}, \mathrm{Ar}-\mathrm{H}), 7.83(\mathrm{~s}, 1 \mathrm{H}$, Arylmethylidene-H), 8.12 (s, $1 \mathrm{H}, \mathrm{NH}) .{ }^{13} \mathrm{C}$ NMR $(75 \mathrm{MHz}$, DMSO): $\delta_{\mathrm{C}} 21.4,21.8,45.35,45.97,79.68,101.64,115.25$, $116.80,126.32,127.18,127.82,128.91,129.45,129.96,130.69$, $131.35,134.73,135.47,135.64,137.90,139.21,146.94,159.17$, 162.90. EIMS: $m / z 369[\mathrm{M}+1]$. Anal. calcd for $\mathrm{C}_{24} \mathrm{H}_{21} \mathrm{~N}_{3} \mathrm{O}: \mathrm{C}$, 78.45; H, 5.76; N, 11.44; found: C, 78.66; H, 5.87; N, 11.35\%.

(E)-8-(4-Chlorobenzylidene)-4-(4-chlorophenyl)-2-oxo-1,2,5,6, 7,8-hexahydro-1,6-naphthyridine-3-carbonitrile (4i). Yellow solid; IR (KBr) $\nu_{\max } 3385,2942,2210,1645,1627 \mathrm{~cm}^{-1} ;{ }^{1} \mathrm{H}$ $\operatorname{NMR}(300 \mathrm{MHz}, \mathrm{DMSO}): \delta_{\mathrm{H}} 3.17\left(\mathrm{~d}, J=15.9 \mathrm{~Hz}, 1 \mathrm{H}, 5-\mathrm{CH}_{2}\right)$, $3.40\left(\mathrm{~d}, J=15.9 \mathrm{~Hz}, 1 \mathrm{H}, 5-\mathrm{CH}_{2}\right), 3.62(\mathrm{~d}, J=15.6 \mathrm{~Hz}, 1 \mathrm{H}, 7-$ $\left.\mathrm{CH}_{2}\right), 3.71\left(\mathrm{~d}, J=15.6 \mathrm{~Hz}, 1 \mathrm{H}, 7-\mathrm{CH}_{2}\right), 7.16-7.48(\mathrm{~m}, 8 \mathrm{H}, \mathrm{Ar}-$ $\mathrm{H}), 7.87$ (s, 1H, Arylmethylidene-H), 8.15 (s, $1 \mathrm{H}, \mathrm{NH}) .{ }^{13} \mathrm{C}$ NMR (75 MHz, DMSO): $\delta_{\mathrm{C}} 45.39,45.94,79.70,101.65,115.26$, $116.81,126.34,127.21,127.85,128.94,129.48,129.91,130.76$, $131.39,134.71,135.51,135.60,137.90,146.92,159.25,162.97$. EIMS: $m / z 409[\mathrm{M}+1]$. Anal. calcd for $\mathrm{C}_{22} \mathrm{H}_{15} \mathrm{Cl}_{2} \mathrm{~N}_{3} \mathrm{O}: \mathrm{C}$, 64.72; H, 3.70; N, 10.29; found: C, 64.95; H, 3.84; N, 10.21\%.

(E)-8-(4-Fluorobenzylidene)-4-(4-fluorophenyl)-2-oxo-1,2,5,6, 7,8-hexahydro-1,6-naphthyridine-3-carbonitrile (4j). Pale yellow solid; IR (KBr) $\nu_{\max } 3387,2940,2213,1645,1624 \mathrm{~cm}^{-1}$; ${ }^{1} \mathrm{H}$ NMR (300 MHz, DMSO): $\delta_{\mathrm{H}} 3.15(\mathrm{~d}, J=15.9 \mathrm{~Hz}, 1 \mathrm{H}, 5-$ $\mathrm{CH}_{2}$ ), 3.37 (d, $\left.J=15.9 \mathrm{~Hz}, 1 \mathrm{H}, 5-\mathrm{CH}_{2}\right), 3.63(\mathrm{~d}, J=15.6 \mathrm{~Hz}$, $\left.1 \mathrm{H}, 7-\mathrm{CH}_{2}\right), 3.70\left(\mathrm{~d}, J=15.9 \mathrm{~Hz}, 1 \mathrm{H}, 7-\mathrm{CH}_{2}\right), 7.13-7.45(\mathrm{~m}, 8 \mathrm{H}$, Ar-H), 7.84 (s, 1H, Arylmethylidene-H), 8.11 (s, $1 \mathrm{H}, \mathrm{NH}) .{ }^{13} \mathrm{C}$ NMR (75 MHz, DMSO): $\delta_{\mathrm{C}} 45.37,45.93,79.72,101.64,114.36$, $114.58,115.23,116.85,126.37,127.84,128.92,129.45,130.72$, $131.35,134.78,135.43,137.94,146.96,159.25,160.23,161.18$, 162.95. EIMS: $m / z 377[\mathrm{M}+1]$. Anal. calcd for $\mathrm{C}_{22} \mathrm{H}_{15} \mathrm{~F}_{2} \mathrm{~N}_{3} \mathrm{O}$ : C, 70.39; H, 4.03; N, 11.19; found: C, 70.65; H, 4.27; N, $11.10 \%$.

(E)-4-(Naphthalen-1-yl)-8-(naphthalen-1-ylmethylene)-2-oxo1,2,5,6,7,8-hexahydro-1,6-naphthyridine-3-carbonitrile (4k). Pale yellow solid; IR (KBr) $v_{\max } 3384,2946,2214,1645$, $1629 \mathrm{~cm}^{-1}$; ${ }^{1} \mathrm{H}$ NMR (300 MHz, DMSO): $\delta_{\mathrm{H}} 3.17(\mathrm{~d}, J=$ $\left.15.9 \mathrm{~Hz}, 1 \mathrm{H}, 5-\mathrm{CH}_{2}\right), 3.41\left(\mathrm{~d}, J=15.9 \mathrm{~Hz}, 1 \mathrm{H}, 5-\mathrm{CH}_{2}\right), 3.61$ $\left(\mathrm{d}, J=15.6 \mathrm{~Hz}, 1 \mathrm{H}, 7-\mathrm{CH}_{2}\right), 3.70\left(\mathrm{~d}, J=15.6 \mathrm{~Hz}, 1 \mathrm{H}, 7-\mathrm{CH}_{2}\right)$, 7.02-7.65 (m, 14H, Ar-H), 7.91 (s, 1H, Arylmethylidene-H), 8.17 (s, $1 \mathrm{H}, \mathrm{NH}) .{ }^{13} \mathrm{C} \mathrm{NMR}(75 \mathrm{MHz}, \mathrm{DMSO}): \delta_{\mathrm{C}} 45.31,45.84$, $79.68,101.65,115.28,116.80,123.46,124.03,125.12,125.57$, $126.30,126.42,126.80,127.20,127.85,128.22,129.12,129.48$, $129.94,130.79,131.43,132.10,132.67,134.73,135.54,135.68$, 137.92, 146.90, 159.28, 162.94. EIMS: $m / z 441[\mathrm{M}+1]$. Anal. calcd for $\mathrm{C}_{30} \mathrm{H}_{21} \mathrm{~N}_{3} \mathrm{O}: \mathrm{C}, 81.98 ; \mathrm{H}, 4.82 ; \mathrm{N}, 9.56$; found: $\mathrm{C}$, 81.80; H, 4.95; N, 9.48\%.

2.2. In Vitro Cholinesterase Enzymes Inhibitory Assay. Cholinesterase inhibitory activity of the synthesized compounds was evaluated using the Ellman's microplate assay [27]. For acetylcholinesterase (AChE) inhibitory assay, $140 \mu \mathrm{L}$ of $0.1 \mathrm{M}$ sodium phosphate buffer ( $\mathrm{pH} \mathrm{8)}$ was first added to a 96well microplate followed by $20 \mu \mathrm{L}$ of test samples and $20 \mu \mathrm{L}$ of 0.09 units $/ \mathrm{mL}$ acetylcholinesterase enzyme from Electrophoruselectricus (Sigma). After 15 minutes of incubation

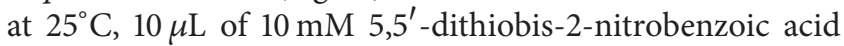
(DTNB) was added into each well followed by $10 \mu \mathrm{L}$ of acetylthiocholine iodide $(14 \mathrm{mM})$. At 30 minutes after the initiation of enzymatic reaction, absorbance of the colored endproduct was measured using BioTek Power Wave X 340 Microplate Spectrophotometer at $412 \mathrm{~nm}$.

Galantamine was used as positive control. Test samples and galantamine were prepared in DMSO at an initial concentration of $1 \mathrm{mg} / \mathrm{mL}$ (1000 ppm). The concentration of DMSO in final reaction mixture was $1 \%$. At this concentration, DMSO has no inhibitory effect on acetylcholinesterase enzyme.

The initial screening was carried out at $10 \mu \mathrm{g} / \mathrm{mL}$ of test samples in $1 \%$ DMSO and each test was conducted in triplicate. Absorbencies of the test samples were corrected by subtracting the absorbance of their respective blank. Percentage enzyme inhibition is calculated using the following formula:

Percentage of inhibition

$$
=\frac{(\text { Absorbance of sample }- \text { Absorbance of control })}{\text { Absorbance of control } \times 100} \text {. }
$$

Subsequently, the determination of $\mathrm{IC}_{50}$ was carried out using a set of five concentrations. 


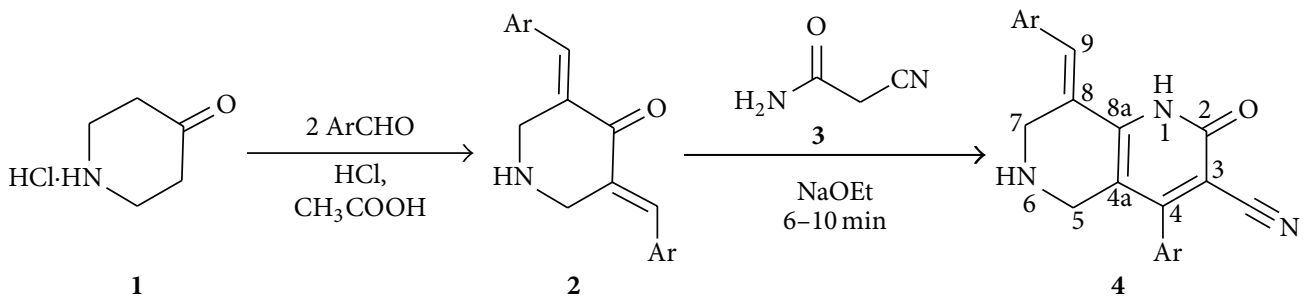

SCHEME 1: Synthesis of naphthyridines (4a-k).

2.3. Molecular Modeling. Using Glide (version 5.7, Schrödinger, LLC, New York, NY, 2011), most active compound was docked onto the active site of TcAChE derived from threedimensional structure of the enzyme complex with antiAlzheimer's drug, galantamine (PDB ID: 4EVE).

Water molecules and hetero groups were deleted from enzyme beyond the radius of $5 \AA$ of reference ligand (galantamine), resulting protein structure refined and minimized by Protein Preparation Wizard using OPLS-2005 force field. Receptor Grid Generation program was used to prepare TcAChE grid and the ligand was optimized by LigPrep program by using OPLS-2005 force field to generate lowest energy state. Docking stimulations were carried out on bioactive compound, handed in 5 poses per ligand, in which the best pose with highest score was displayed for each ligand.

\section{Results and Discussion}

3.1. Chemistry. In the present investigation, the reaction of a series of bisarylmethylidene piperidones with 2-cyanoacetamide in the presence of sodium ethoxide with few drops of ethanol under simple mixing at ambient temperature for 6-10 min afforded functionalized 1,6-naphthyridines in good yields (65-78\%; Scheme 1). The prerequisite bisarylmethylidene piperidones were synthesized following the literature reported method [28]. In a typical reaction, an equimolar mixture of 3,5-bis[(E)-2-methylphenylmethylidene] tetrahydro-4 $(1 H)$-pyridinones $(\mathbf{2 b})$ and 2-cyanoacetamide (3) in catalytic amount of sodium ethoxide were ground well in a semimicro boiling tube with few drops of ethanol at ambient temperature for about $7 \mathrm{~min}$ and after completion of the reaction water was added to the mixture and the product was filtered and dried in vacuo. In this case, the 2-pyridone was obtained as a sole reaction product and does not require column chromatography for purification. Easy availability of the reagents, short reaction time, and simple reaction condition rendered this method more attractive from the viewpoint of green chemistry.

The structure of 1,6-naphthyridines was elucidated using IR, NMR, and CHN analysis. In the ${ }^{1} \mathrm{H}$ NMR spectrum of 4b, the two doublets at 3.14 and $3.33 \mathrm{ppm}$ with $J=15.9 \mathrm{~Hz}$ are due to $5-\mathrm{CH}_{2}$ protons while the other doublets at 3.62 and $3.68 \mathrm{ppm}$ with $J=15.6 \mathrm{~Hz}$ are due to $7-\mathrm{CH}_{2}$ protons of the piperidine ring. The singlets at 8.14 and $7.80 \mathrm{ppm}$ can be attributed to the $\mathrm{NH}$ of 2-pyridone ring and arylmethylidene proton, respectively. The two $-\mathrm{CH}_{3}$ protons of aromatic ring appear as singlets at 2.13 and $2.30 \mathrm{ppm}$ while the multiplets around $7.04-7.35 \mathrm{ppm}$ are due to aromatic protons. In the ${ }^{13} \mathrm{C} \mathrm{NMR}$ spectrum, the chemical shifts at 19.75 and $20.56 \mathrm{ppm}$ were due to the two $-\mathrm{CH}_{3}$ carbons whilst the two methylene carbons of the piperidine ring resonated at 45.43 and $45.82 \mathrm{ppm}$. The aromatic carbons resonated at $101.32-162.92 \mathrm{ppm}$. The molecular ion peak at $369[\mathrm{M}+1]$ confirms the presence of compound $\mathbf{4 b}$. The elemental analysis result of $\mathbf{4 b}$ was within $\pm 0.4 \%$ of the theoretical values. The structure of other 2-pyridones was also assigned by similar considerations. Presumably, the 1,6naphthyridine (4) is formed via a cascade heterocyclization mechanism involving an initial Michael addition followed by cyclization and air oxidation as reported by Jain et al. [29].

3.2. In Vitro Evaluation. All newly synthesized 1,6-naphthyridines were evaluated in vitro for their inhibitory potential against AChE enzyme from electric eel using colorimetric Ellman's method (Table 1). All the 1,6-naphthyridines (4a-k) displayed good to moderate inhibitory activities with $\mathrm{IC}_{50}$ values ranging from 2.12 to $24.72 \mu \mathrm{M}$, irrespective of the position of the substituent on the aryl ring. Among the 1,6-naphthyridines, compounds $4 \mathbf{i}$ with $p$-chloro, $4 \mathbf{k}$ with 1naphthyl, $4 \mathrm{~h}$ with $p$-methyl, and $\mathbf{4 b}$ with $o$-methyl substituent in the aromatic ring displayed good activities $(<10 \mu \mathrm{M})$ with $\mathrm{IC}_{50} 3.86 \mu \mathrm{M}, 6.86 \mu \mathrm{M}, 7.16 \mu \mathrm{M}$, and $7.20 \mu \mathrm{M}$, respectively. Compounds $\mathbf{4 a}, \mathbf{4 c}, \mathbf{4 d}, \mathbf{4 g}$, and $\mathbf{4 j}$ displayed moderate activities $\left(\mathrm{IC}_{50}=11.18-18.16 \mu \mathrm{M}\right)$ while compound $4 \mathrm{f}$ displayed the lowest activity $\left(\mathrm{IC}_{50}=24.72 \mu \mathrm{M}\right)$. Compound $4 \mathrm{e}$ with $o$-methoxy phenyl rings displayed the highest activity with $\mathrm{IC}_{50}$ value of $2.12 \mu \mathrm{M}$, comparable to the standard drug galantamine $\left(\mathrm{IC}_{50}=2.09 \mu \mathrm{M}\right)$. It is also observed that the AChE inhibitory activities were directly correlated to the size of substituents in the phenyl ring. For instance, derivative bearing bulky moieties, such as $m$-nitro, $o, p$-dichloro, and $p$-bromo, displayed lower inhibition than the derivatives carrying smaller functions irrespective of their position in the phenyl ring.

The active site of AChE enzyme is located inside a $20 \AA$ long, narrow gorge which is dominantly composed of amino acids possessing aromatic side chains such as tryptophan and tyrosine. Therefore, the derivatives bearing a relatively small and/or electron donating moieties in phenyl rings, such as methyl and methoxy, displayed better inhibitory activities than derivatives carrying bulky and/or electron withdrawing groups, plausibly due to the better insertion into the active site channel and also more efficient binding interaction with aforementioned aromatic residues. However with limited 
TABLE 1: Physical data and AChE inhibitory activity of naphthyridines (4a-k).

\begin{tabular}{|c|c|c|c|c|c|}
\hline Entry & Product & Reaction time (min) & $\begin{array}{c}\text { Yield } \\
(\%)\end{array}$ & $m p{ }^{\circ} \mathrm{C}$ & $\begin{array}{l}\text { AChE inhibition } \\
\left(\mathrm{IC}_{50} \pm \mathrm{SD}\right) \mathrm{mol} / \mathrm{L}\end{array}$ \\
\hline 1 & & 8 & 75 & $211-212$ & $11.18 \pm 0.02$ \\
\hline 2 & & 7 & 72 & $229-230$ & $7.20 \pm 0.02$ \\
\hline 3 & & 7 & 76 & $220-221$ & $15.21 \pm 0.1$ \\
\hline 4 & & 6 & 70 & 208-209 & $18.16 \pm 0.02$ \\
\hline 5 & & 9 & 67 & $215-216$ & $2.12 \pm 0.02$ \\
\hline
\end{tabular}


TABle 1: Continued.

Entry

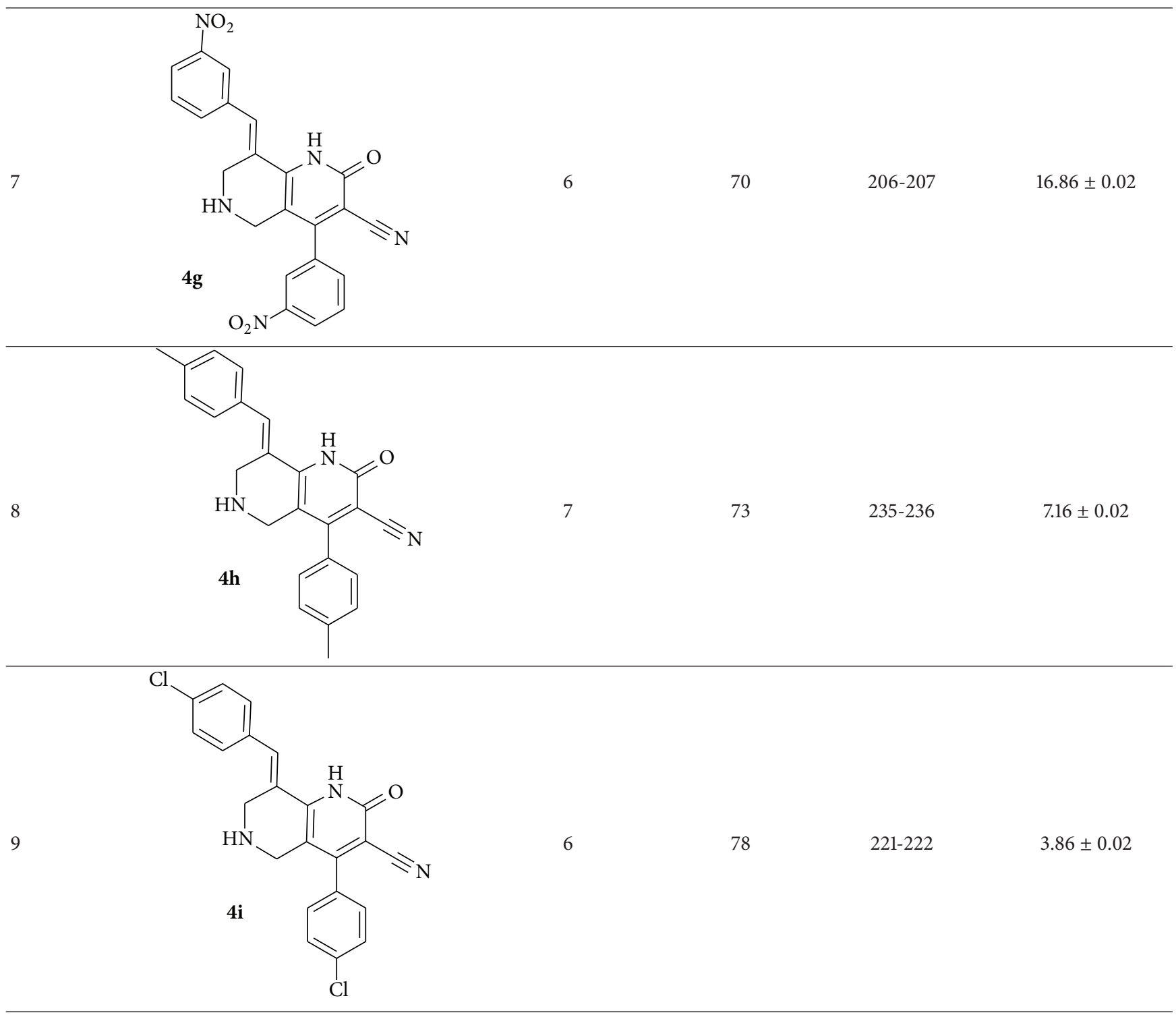


TABle 1: Continued.

Entry

substituent on the aryl ring, it is difficult to ascertain the exact structure activity relationship based on their activities observed.

3.3. Docking Studies. The most active AChE inhibitor, $\mathbf{4 e}$, was docked into the active site of AChE enzyme derived from crystal structure of Torpedo californica AChE (TcAChE). The docking analysis revealed that this compound is properly inserted into the active site of AChE enzyme with free binding energy of $8.71 \mathrm{kcal} / \mathrm{mol}$ and strongly bound to the residues comprising aromatic side chains such as Tyr70 $(\mathrm{H}-$ bonding $1.16 \AA$ ), Tyr121 (hydrophobic), Tyr334 (hydrophobic) at peripheral anionic site as well as Phe330 (hydrophobic), and Trp84 ( $\pi, \pi$-stacking) at choline binding site of the enzyme (Figure 1). 4e also exhibited mild polar interaction with Glyl16 and Glyl17 at oxyanion hole of the AChE enzyme. The crystal structure of the TcAChE in complex with available $\mathrm{AD}$ drugs such as galantamine and huperzine A showed similar interactions with residues composing peripheral anionic site along with stacking against Trp84 at bottom of the gorge. It seems that the presence of methoxy group in $4 \mathbf{e}$ has notable influence on proper positioning of this compound in $\mathrm{AChE}$ active site. This orientation effectively avoids insertion and hydrolysis of substrate inside the AChE active site channel and completely coincides with the activity observed for this compound.

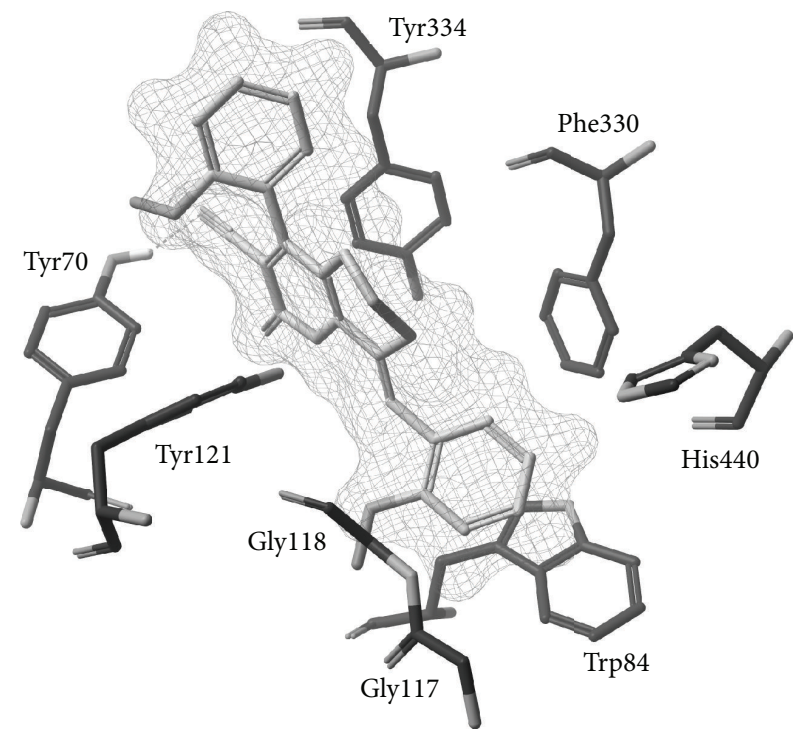

Figure 1: Binding interaction of $4 \mathbf{e}$ with active site of AChE receptor. (Hydrogen atoms are not shown for clarity.)

\section{Conclusion}

A series of novel 1,6-naphthyridines were synthesized in good yields and evaluated for their inhibitory potentials against AChE enzyme, using colorimetric Ellman's method. 
Among them, compound $\mathbf{4 e}$ displayed the highest $\mathrm{AChE}$ inhibition with remarkable $\mathrm{IC}_{50}$ value of $2.12 \mu \mathrm{M}$, comparable to standard drug, galantamine. Molecular modeling analysis for this compound manifested its orientation inside the active site cavity and its effective binding interactions to the residues lining the active site channel, which coincided with its in vitro activity.

\section{Conflict of Interests}

The authors confirm that this paper content has no conflict of interests.

\section{Acknowledgment}

The authors acknowledge the Deanship of Scientific Research at King Saud University for the Research Grant RGP-VPP026.

\section{References}

[1] A. Nordberg, "Biological markers and the cholinergic hypothesis in Alzheimer's disease," Acta Neurologica Scandinavica, vol. 85 , no. 139 , pp. 54-58, 1992.

[2] A. V. Terry Jr. and J. J. Buccafusco, “The cholinergic hypothesis of age and Alzheimer's disease-related cognitive deficits: recent challenges and their implications for novel drug development," The Journal of Pharmacology and Experimental Therapeutics, vol. 306, no. 3, pp. 821-827, 2003.

[3] M. Prince, R. Bryce, and C. Ferri, World Alzheimer Report 2011: The Benefits of Early Diagnosis and Intervention, Alzheimer's Disease International (ADI), London, UK, 2011.

[4] P. T. Nelson, E. Head, F. A. Schmitt et al., "Alzheimer's disease is not 'brain aging': neuropathological, genetic, and epidemiological human studies," Acta Neuropathologica, vol. 121, no. 5, pp. 571-587, 2011.

[5] N. Tabet, "Acetylcholinesterase inhibitors for Alzheimer's disease: anti-inflammatories in acetylcholine clothing!" Age and Ageing, vol. 35, no. 4, pp. 336-338, 2006.

[6] E. Giacobini, "Cholinesterase inhibitors: new roles and therapeutic alternatives," Pharmacological Research, vol. 50, no. 4, pp. 433-440, 2004.

[7] E. Giacobini, "Invited review. Cholinesterase inhibitors for Alzheimer's disease therapy: from tacrine to future applications," Neurochemistry International, vol. 32, no. 5-6, pp. 413419, 1998.

[8] A. Rampa, L. Piazzi, F. Belluti et al., "Acetylcholinesterase inhibitors: SAR and kinetic studies on omega-[N-methyl- $N$-(3-alkylcarbamoyloxyphenyl)methyl]-amino-alkoxyaryl derivatives," Journal of Medicinal Chemistry, vol. 44, no. 23, pp. 3810-3820, 2001.

[9] R. Morphy and Z. Rankovic, "Designed multiple ligands. An emerging drug discovery paradigm," Journal of Medicinal Chemistry, vol. 48, no. 21, pp. 6523-6543, 2005.

[10] A. Cavalli, M. L. Bolognesi, A. Minarini et al., "Multi-targetdirected ligands to combat neurodegenerative diseases," Journal of Medicinal Chemistry, vol. 51, no. 7, pp. 347-372, 2008.

[11] A. J. Larner, "Alzheimer's disease: targets for drug development," Mini-Reviews in Medicinal Chemistry, vol. 2, no. 1, pp. 1-9, 2002.
[12] J. Y. Melamed, M. S. Egbertson, S. Varga et al., "Synthesis of 5-(1-H or 1-alkyl-5-oxopyrrolidin-3-yl)-8-hydroxy-[1,6]-naphthyridine-7-carboxamide inhibitors of HIV-1 integrase," Bioorganic and Medicinal Chemistry Letters, vol. 18, no. 19, pp. 53075310, 2008.

[13] M. S. Egbertson, H. M. Moritz, J. Y. Melamed et al., "A potent and orally active HIV-1 integrase inhibitor," Bioorganic and Medicinal Chemistry Letters, vol. 17, no. 5, pp. 1392-1398, 2007.

[14] G. Falardeau, H. Lachance, A. S. Pierre et al., "Design and synthesis of a potent macrocyclic 1,6-napthyridine anti-human cytomegalovirus (HCMV) inhibitors," Bioorganic and Medicinal Chemistry Letters, vol. 15, no. 6, pp. 1693-1695, 2005.

[15] L. Chan, H. Jin, T. Stefanac et al., "Discovery of 1,6-naphthyridines as a novel class of potent and selective human cytomegalovirus inhibitors," Journal of Medicinal Chemistry, vol. 42, no. 16, pp. 3023-3025, 1999.

[16] A. M. Thompson, C. J. C. Connolly, J. M. Hamby et al., "3(3,5-Dime-thoxyphenyl)-1,6-naphthyridine-2,7-diamines and related 2-urea derivatives are potent and selective inhibitors of the FGF receptor-1 tyrosine kinase," Journal of Medicinal Chemistry, vol. 43, no. 22, pp. 4200-4211, 2000.

[17] S. Vanlaer, A. Voet, C. Gielens, M. de Maeyer, and F. Compernolle, "Bridged 5,6,7,8-tetrahydro-1,6-naphthyridines, analogues of huperzine A: synthesis, modelling studies and evaluation as inhibitors of acetylcholinesterase," European Journal of Organic Chemistry, no. 5, pp. 643-654, 2009.

[18] M. N. Jachak, S. M. Bagul, M. A. Kazi, and R. B. Toche, "Novel synthetic protocol toward pyrazolo[3,4-h]-[1,6] naphthyridines via Friedlander condensation of new 4-aminopyrazolo[3,4- $b]$ pyridine-5-carbaldehyde with reactive $\alpha$-methylene ketones," Journal of Heterocyclic Chemistry, vol. 48, no. 2, pp. 295-300, 2011.

[19] R. V. Rote, S. M. Bagul, D. P. Shelar, S. R. Patil, R. B. Toche, and M. N. Jachak, "Synthesis of benzo[3,4- $h][1,6]$ naphthyridines via Friedländer condensation with active methylenes," Journal of Heterocyclic Chemistry, vol. 48, no. 2, pp. 301-307, 2011.

[20] R. B. Toche, B. P. Pagar, R. R. Zoman, G. R. Shinde, and M. N. Jachak, "Synthesis of novel benzo[ $h][1,6]$ naphthyridine derivatives from 4 -aminoquinoline and cyclic $\beta$-ketoester," Tetrahedron, vol. 66, no. 27-28, pp. 5204-5211, 2010.

[21] A. Chandra, B. Singh, S. Upadhyay, and R. M. Singh, "Copperfree Sonogashira coupling of 2-chloroquinolines with phenyl acetylene and quick annulation to benzo $[b][1,6]$ naphthyridine derivatives in aqueous ammonia," Tetrahedron, vol. 64, no. 51, pp. 11680-11685, 2008.

[22] A. Basiri, V. Murugaiyah, H. Osman, R. S. Kumar, Y. Kia, and M. A. Ali, "Microwave assisted synthesis, cholinesterase enzymes inhibitory activities and molecular docking studies of new pyridopyrimidine derivatives," Bioorganic and Medicinal Chemistry, vol. 21, no. 11, pp. 3022-3031, 2013.

[23] Y. Kia, H. Osman, R. S. Kumar et al., "A facile chemo-, regio- and stereoselective synthesis and cholinesterase inhibitory activity of spirooxindole-pyrrolizine-piperidine hybrids," Bioorganic and Medicinal Chemistry Letters, vol. 23, no. 10, pp. 2979-2983, 2013.

[24] A. Basiri, V. Murugaiyah, H. Osman et al., "An expedient, ionic liquid mediated multi-component synthesis of novel piperidone grafted cholinesterase enzymes inhibitors and their molecular modeling study," European Journal of Medicinal Chemistry, vol. 67, pp. 221-229, 2013.

[25] R. S. Kumar, A. Ramar, S. Perumal, A. I. Almansour, N. Arumugam, and M. A. Ali, "Three-component synthesis and 1,3-dipo- 
lar cycloaddition of highly functionalized pyrans with nitrile oxides: easy access to 1,2,4-oxadiazoles," Synthetic Communications, vol. 43, no. 20, pp. 2763-2772, 2013.

[26] R. S. Kumar, A. I. Almansour, N. Arumugam et al., "An expedient synthesis and screening for antiacetylcholinesterase activity of piperidine embedded novel pentacyclic cage compounds," Medicinal Chemistry, vol. 10, no. 2, pp. 228-236, 2014.

[27] G. L. Ellman, K. D. Courtney, V. Andres Jr., and R. M. Featherstone, "A new and rapid colorimetric determination of acetylcholinesterase activity," Biochemical Pharmacology, vol. 7, no. 2, pp. 88-95, 1961.

[28] J. R. Dimmock, M. P. Padmanilayam, R. N. Puthucode et al., "A conformational and structure-activity relationship study of cytotoxic 3,5-bis(arylidene)-4-piperidones and related Nacryloyl analogues," Journal of Medicinal Chemistry, vol. 44, no. 4, pp. 586-593, 2001.

[29] R. Jain, F. Roschangar, and M. A. Ciufolini, "A one-step preparation of functionalized 3-cyano-2-pyridones," Tetrahedron Letters, vol. 36, no. 19, pp. 3307-3310, 1995. 

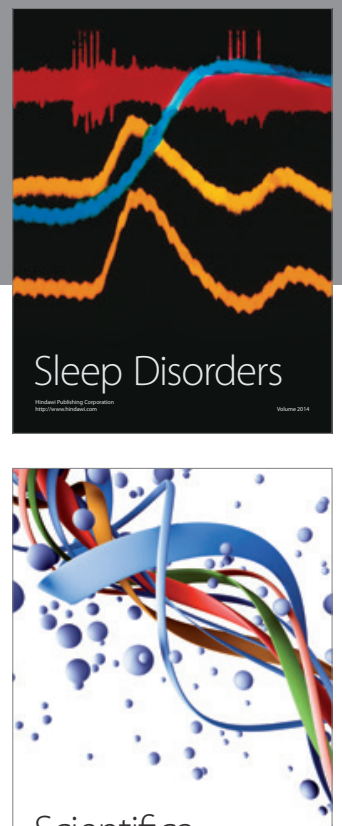

Scientifica
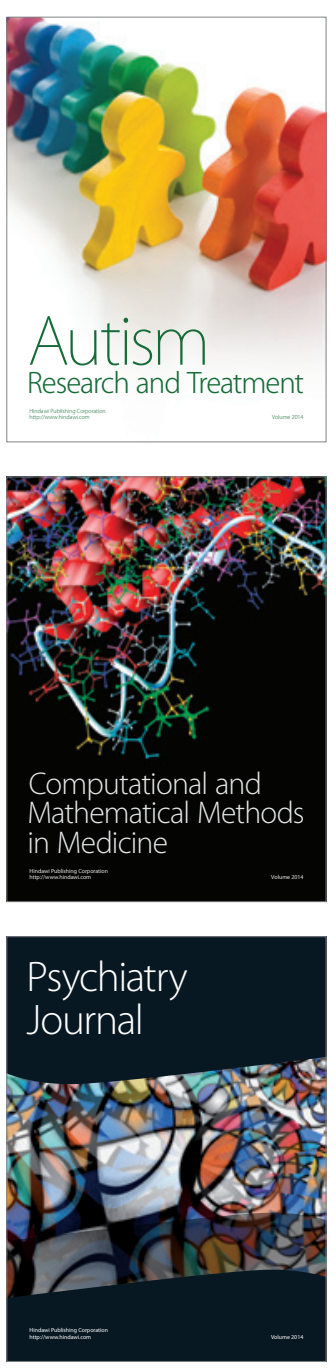
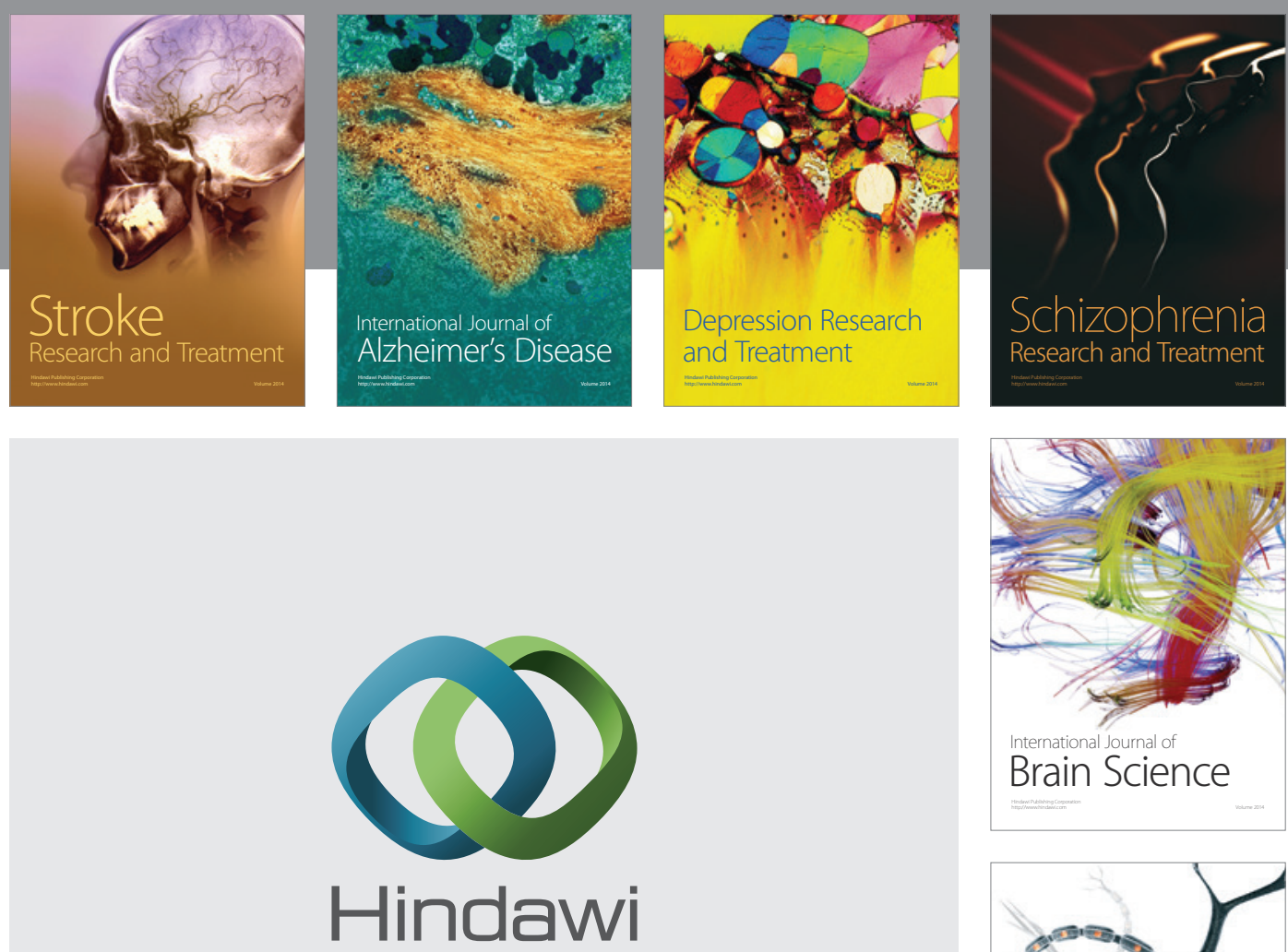

Submit your manuscripts at

http://www.hindawi.com
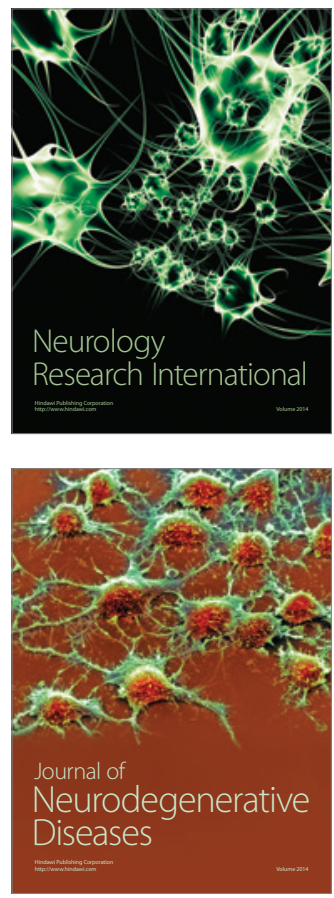

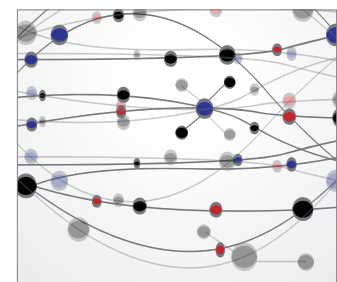

The Scientific World Journal
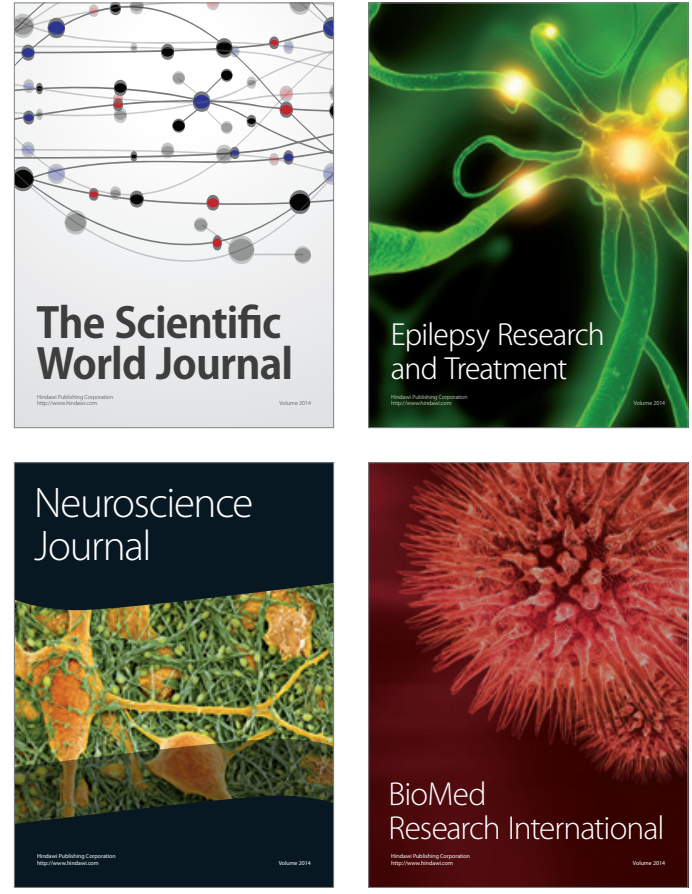

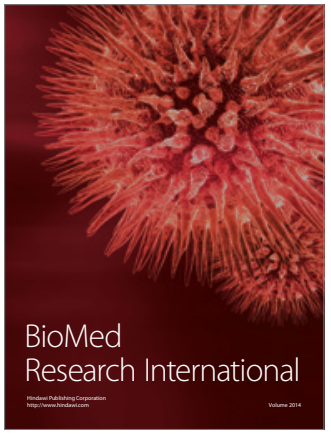

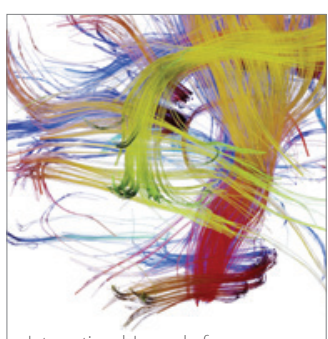

Brain Science

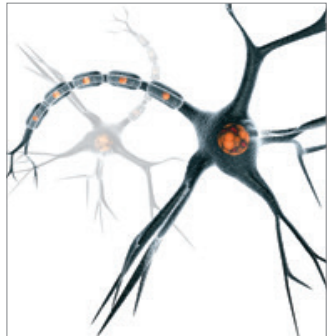

Neural Plasticity
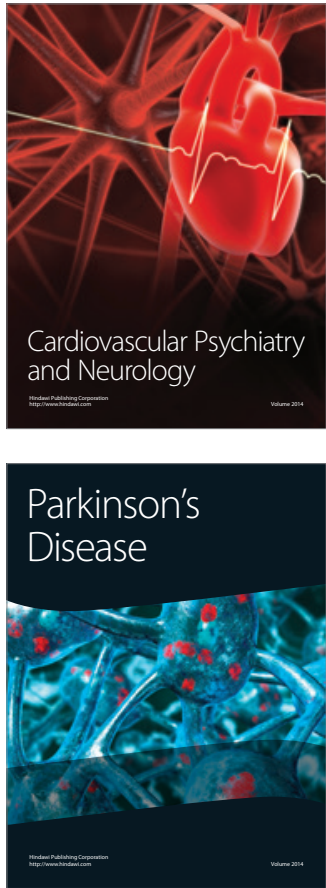